\title{
Analisis Ekonomi Teknik Desain Polder di Wilayah Semarang Timur
}

\author{
Rizka Arbaningrum \\ Program Studi Teknik Sipil, Universitas Pembangunan Jaya \\ rizka.arbaningrum@upj.ac.id
}

\begin{abstract}
Flood and rob problems often occur in the East Semarang area, this results in economic losses. In order to improve this condition, permanent handling is needed, namely by making a polder system for the East Semarang Region. The initial stages start from calculating the estimated construction costs, procuring pumps, land acquisition and operating and maintenance costs for the pump. The estimated annual operating and maintenance costs of the pump are Rp. 8,012,756,880.00. The estimated cost of land acquisition is Rp. 750,000,000.00 / hectare. The estimated construction cost of Rp. 574,168,000,000.00. The estimated cost of procuring a pump is Rp. 18,000,000,000.00. Economic parameter NPV is Rp. 327,660,000,000,00 and NBC is 1.39. So that can be concluded that selected design with economic cost and polder system development in East Semarang Region is economically feasible.
\end{abstract}

Keywords : Flood and robs, Polder System; Economic design

\begin{abstract}
Abstrak : Permasalahan banjir dan rob sering terjadi di wilayah Semarang Timur, hal ini mengakibatkan kerugian ekonomi. Guna memperbaiki kondisi tersebut maka diperlukan penanganan secara permanen yaitu dengan pembuatan sistem polder untuk Wilayah Semarang Timur. Tahapan awal di mulai dari perhitungan estimasi biaya konstruksi, pengadaan pompa, pembebasan lahan serta biaya operasional dan pemeliharaan pompa. Estimasi biaya operasional dan pemeliharaan pompa dalam setahun yaitu Rp 8.012.756.880,00. Estimasi biaya pembebasan lahan yaitu Rp 750.000.000,00/hektar. Estimasi biaya konstruksi Rp 574.168.000.000,00. Estimasi biaya pengadaan pompa Rp 18.000.000.000,00. Didapat parameter ekonomi NPV sebesar Rp 327.660.000.000,00 dan NBC sebsar 1,39. Sehingga dapat disimpulkan bahwa desain terpilih merupakan desain dengan biaya yang ekonomis serta pembangunan sistem polder Wilayah Semarang Timur layak secara ekonomi.

Kata Kunci : Banjir dan rob, Sistem Polder, Desain Ekonomis
\end{abstract}

\section{PENDAHULUAN \\ Latar Belakang}

Kota Semarang memiliki letak strategis sebagai ibukota Provinsi Jawa Tengah dan berkembang sebagai kota perdagangan dan industri. Kota Semarang dilalui jalur transportasi pantai utara (Pantura) yang sangat vital dalam perekonomian nasional. Wilayah Semarang Timur merupakan salah satu jalur utama Pantura dan sekaligus sebagai pintu gerbang Kota Semarang dari arah timur. Lalu lintas di Wilayah Semarang Timur saat ini sering mengalami kelumpuhan karena terjadi banjir dan rob. Disamping kemacetan lalu lintas, banjir dan rob juga menggenangi Wilayah Semarang timur secara keseluruhan sehingga mengakibatkan kerusakan infrastruktur, lingkungan industri, perkantoran, pendidikan, rumah sakit dan pemukiman.
Faktor utama penyebab rob adalah kenaikan muka air laut yang lebih tinggi dari pada permukaan lahan/daratan di kawasan pesisir, sehingga air laut masuk menggenangi daratan, baik masuk secara langsung maupun melalui alur sungai. Namun, untuk kawasan pesisir, rob diperparah dengan adanya penurunan tanah di daerah tersebut. Hal ini terjadi terutama di kota-kota dengan tingkat pembangunan tinggi dan berada di kawasan pesisir seperti Kota Semarang.

Guna memperbaiki kondisi tersebut serta mengantisipasi kemungkinan terjadinya permasalahan banjir dan rob yang semakin kompleks, maka diperlukan penanganan secara permanen agar banjir dan rob bisa ditanggulangi secara jangka panjang. Salah satu rencana untuk menangani banjir rob yaitu dengan pembuatan sistem polder untuk Wilayah Semarang Timur, dengan dibatasi Tanggul kanan di Kanal Banjir Timur dan Tanggul 
kiri di Sungai Babon. Sistem polder terdiri dari tanggul laut, kolam retensi dan rumah pompa.

Dalam perencanaan, pelaksanaan dan pengelolaan sistem polder ini membutuhkan biaya yang tidak sedikit. Sehingga diperlukan analisis ekonomi teknik untuk mengetahui kelayakan ekonomi pada Sistem Polder di Wilayah Semarang TImur

\section{Formulasi Masalah}

Berdasarkan latar belakang seperti dijelaskan di atas, dapat disimpulkan rumusan masalah pada penelitian ini, yaitu:

1. Bagaimanakah pengaruh dari Biaya Perencanaan, Pelaksanaan dan Pengelolaan pada analisis ekonomi teknik?

2. Bagaimanakah kelayakan ekonomi pada Sistem Polder di Wilayah Semarang Timur?

\section{Tujuan}

Maksud dari Analisis ini adalah untuk mengetahui kelayak ekonomi pada sistem polder tersebut. Selain itu, penelitian ini diharapkan dapat digunakan sebagai referensi dalam perencanaan sistem polder di lokasi yang sejenis seperti di Wilayah Semarang Timur. Tujuan analisis ini antara lain :

1. Mendapatkan nilai Net Benefit Cost Ratio;

2. Mendapatkan nilai Net Present Value;

3. Mendapatkan nilai Internal Rate of Return;

4. Mengetahui kelayakan ekonomi pada Sistem Polder di Wilayah Semarang Timur

\section{Sistematika Penulisan}

Penelitian ini dibagi menjadi enam bab dengan sistematika penulisan sebagai berikut :

\section{PENDAHULUAN}

Berisi mengenai latar belakang, formulasi masalah, tujuan dan sistematika penulisan yang berkaitan dengan materi penelitian ini.

2. KAJIAN PUSTAKA

Menjelaskan kajian teori dan ulasan ringkasan teori yang digunakan dalam penelitian ini. Teori yang digunakan berkaitan dengan proses penelitian serta tinjauan pustaka dari laporan-laporan sebelumnya yang berhubungan dengan penelitian ini.

\section{METODOLOGI PENELITIAN}

Menejelaskan uraian pelaksanaan penelitian mulai dari tahap persiapan, pengumpulan data analisis hingga metode.

4. HASIL PENELITIAN DAN

\section{ANALISIS}

Menguraikan tentang proses analisis data seperti analisis penetuan lokasi penelitian, analisis data hujan, analisis debit banjir, pemodelan kolam retensi, perhitungan biaya pembebasan lahan dan operasional pemeliharaan pompa, simulasi desain, ekonomi teknik dan perbandingan dengan studi terdahulu.

5. KESIMPULAN

Berisi kesimpulan simulasi berdsarkan hasil penelitian yang diperoleh sebagai masukan pembaca maupun penelitian selanjutnya.

6. SARAN

Berisikan saran-saran yang didapat dalam penelitian.

\section{KAJIAN PUSTAKA \\ Sistem Polder}

Polder didefinisikan sebagai suatu kawasan atau lahan reklamasi, dengan kondisi awal mempunyai muka air tanah tinggi, yang diisolasi secara hidrologis dari daerah di sekitarnya dan kondisi muka air (air permukaan dan air tanah) dapat dikendalikan. Kondisi lahanya sendiri dibiarkan pada elevasi asalnya atau sedikit ditinggikan (Suripin, 2004). Komponenkomponen yang ada pada sistem polder meliputi :

1. Taggul keliling dan/atau pertahanan laut (sea defense) atau konstruksi isolasi lainya. 
2. Sistem drainase lapangan (field drainage system).

3. Sistem pembawa (conveyor system).

4. Kolam penampung dan stasiun pompa (outfall system).

5. Badan air penerima (recipient waters).

\section{Ekonomi Teknik}

Tinjauan Kelayakan suatu pekerjaan konstruksi dari sisi Ekonomi adalah salah satu syarat penting dalam perencanaan dan pelaksanaan suatu pekerjaan konstruksi Teknik Sipil, dan bahkan pekerjaan bentuk lain. Apalagi bila pekerjaan konstruksi tersebut cukup besar dari segi dana, dan melibatkan masyarakat. Syarat lain yang cukup vital adalah layak sosial, layak lingkungan (amdal), dan layak kekokohan (Pranoto,2003).

Dalam Ekonomi Rekayasa ini, akan dipelajari Kreteria Peninjauan Investasi : NBC, NPV dan IRR. Hal ini disampaikan (NBC, NPV, IRR) karena formula tersebut sering digunakan dalam aplikasi lapangan, dan diyakini hasilnya cukup handal.

\section{Investasi}

Kegitan investasi merupakan kegiatan penting yang memerlukan biaya besar dan berdampak jangka panjang terhadap kelanjutan usaha (Giatman, 2006). Oleh karena itu, analisis sistematis dan rasional sangan dibutuhkan sebelum kegiatan direalisasikan. Suatu investasi merupakan kegiatan menanamkan modal jangka panjang, dimana selain investasi tersebut perlu pula disadari dari awal bahwa investasi akan diikuti sejumlah pengeluaran lain yang secara periodic peru di sipakan. Pengeluaran tersebut terdiri dari biaya operasional, perawatan dan biaya-biaya yang lainya yang tidak dapat di hindarkan.

\section{Biaya}

Pada pelaksanaan pembangunan, mulai dari ide, studi kelayakan, perencanaan, pelaksanaan, sampai pada operasi dan pemeliharaan membutuhkan bermacam-macam biaya. Pada analisis kelayan ekonomi biaya-biaya tersebut dikelompokan menjadi beberapa komponen sehingga memudahkan analisis perhitunganya. Menurut Kuiper (1971) semua biaya itu dikelompokan menjadi dua yaitu biaya modal dan biaya tahunan.

1. Biaya Modal (Capital Cost)

Biaya modal adalah jumlah semua pengeluaran yang dibutuhkan mulai dari pra studi sampai proyek selesai di bangun (Kuiper dalam Kodoatie, 2001).

2. Biaya Tahunan

Waktu sebuah pekerjaan selesai dibangun merupakan waktu awal dari umur proyek sesuai dengan rekayasa teknik yang telah dibuat pada waktu detail desain. Biaya tahunan merupakan biaya yang masih diperlukan sepanjang umur proyek.Beban biaya tahunan masih harus di pikul oleh pihak pemilik/investor (Kodoatie, 2001).

\section{Net Benefit Cost Ratio (NBC)}

NBC adalah perbandingan antara nilai ekivalen dari benefit (manfaat/+) dengan nilai ekivalen dari cost (biaya/-) pada suatu titik waktu yang sama, misalnya present worth (sekarang), future worth (yang akan datang) ataupun annual worth.

Secara umum persamaan yang digunakan untuk perhitungannya dapat diuraikan sebagai berikut:

$\mathrm{NBC}=\sum_{0}^{t} \frac{P V b-P V c}{P V b-P V c} \quad\left(\frac{\text { yangbernilai }>0}{\text { yangbernilai }<0}\right)$

Apabila NBC $\geq 1$, maka proyek layak untuk dilaksanakan; Apabila NBC < 1, maka proyek tidak layak untuk dilaksanakan.

\section{Net Present Value (NPV)}

NPV merupakan jumlah keseluruhan manfaat (benefit) dikurangi dengan keseluruhan biaya (cost) pada suatu titik yang sama, misalkan present worth, future worth, ataupun annual worth. Sehingga rumus perhitungan $N P V$ adalah:

$N P V=\sum_{t=1}^{t=n} \frac{\left(B_{t}-C_{t}\right)}{(1+i)^{t}}$ 
NPV positif atau $\geq 0$, maka proyek layak dilaksanakan; NPV negatif atau $<0$, maka proyek tidak layak untuk dilaksanakan.

\section{Internal Rate of Return (IRR)}

$I R R$ adalah nilai suku bunga yang diperoleh jika $B C R$ bernilai sama dengan 1 atau nilai suku bunga yang diperoleh jika $N P V$ bernilai sama dengan 0 (nol). IRR dihitung atas dasar pendapatan per tahun bersih dan total investasi yang diperlukan.Nilai IRR sangat penting diketahui untuk melihat sejauh mana kemampuan proyek ini dapat dibiayai dengan melihat suku bunga pinjaman yang berlaku.

$I R R=\sum_{t=1}^{t=n} \frac{\left(B_{t}-C_{t}\right)}{(1+i)^{t}}=0$

Apabila nilai $I R R \geq$ suku bunga yang ditetapkan, maka proyek layak untuk dilaksanakan. Namun bila $I R R<$ suku bunga yang ditetapkan, maka proyek tidak layak untuk dilaksanakan.

\section{METODOLOGI PENELITIAN}

Tahapan pengolahan data pada penelitian ini adalah sebagai berikut :

a. Analisis Biaya Investasi

- Biaya Pembebasan Lahan

Lahan yang akan direncanakan untuk lokasi kolam retensi merupakan lahan tambak milik warga dan swasta, sehingga dibutuhkan dana untuk pembebasan lahan tersebut. Dalam analisis ini dana yang di gunakan untuk pembebasan lahan di dapat dari survey harga $\operatorname{tanah} / \mathrm{m}^{2}$ di Wilayah Semarang Timur.

- Biaya Konstruksi

Biaya konstruksi didapat dari perhitungan desain yang telah di lakukan oleh BBWS Pemali-Juana.

- Biaya Konsultan Teknik

Biaya teknik yang dibutuhkan dalam proyek pembangunan Sistem polder Semarang Timur diperkirakan sebesar $15 \%$ dari keseluruhan biaya konstruksi.

b. Analisis Biaya Manfaat
Biaya manfaat pengendalian banjir dapat diketahui dari biaya kerugian akibat terjadinya banjir dan rob. Kerugian ekonomi akibat banjir dan rob dapat di hitung berdasarkan nilai ekonomi setiap penggunaan lahan. Pada penelitian ini, nilai ekonomi setiap penggunaan lahan wilayah semarang didasarkan pada penelitian lahan yang telah dilakukan oleh Ifan R Suhelmi, dkk (2013).



Gambar 1. Diagram Alir Penelitian

c. Analisis Biaya Operasional dan Pemeliharaan 
Biaya kegiatan operasional dan pemeliharaan harus di rencanakan terlebih dahulu, untuk mengestimasi pengeluaran-pengeluaran kegiatan operasional dan pemeliharaan. Biaya operasional pompa diperhitungkan dengan 2 sumber pemakaian, yaitu menggunakan listrik PLN dan Genset. Apabila sumber PLN tidak bisa digunakan karena adanya gangguan, maka sumber dari genset yang akan bekerja.

d. Analisis Perhitungan Parameter Ekonomi Nilai Net Benefit Cost Ratio, Nilai Net Present Value dan Nilai Internal Rate of Return

\section{HASIL PENELITIAN DAN ANALISIS Analisis Lokasi Kolam Retensi}

Analisis pertama yang dilakukan pada penelitian ini adalah menganalisis wilayah yang akan dijadikan lokasi kolam retensi (Gambar 2). Daerah yang dijadikan sebagai lokasi kolam direncanakan berada di daerah hilir Sungai Tenggang dan Sungai Sringin yang telah tergenang oleh masuknya air laut.

Berdasarkan pada peta topografi dan pecitraan satelit dapat diperkirakan lias lahan yang berpotensi menjadi kolam retensi memiliki luas \pm 300 hektar. Pada penelitian ini akan di modelkan luas kolam retensi 100 hektar hingga 300 hektar dengan interval 10 hektar.

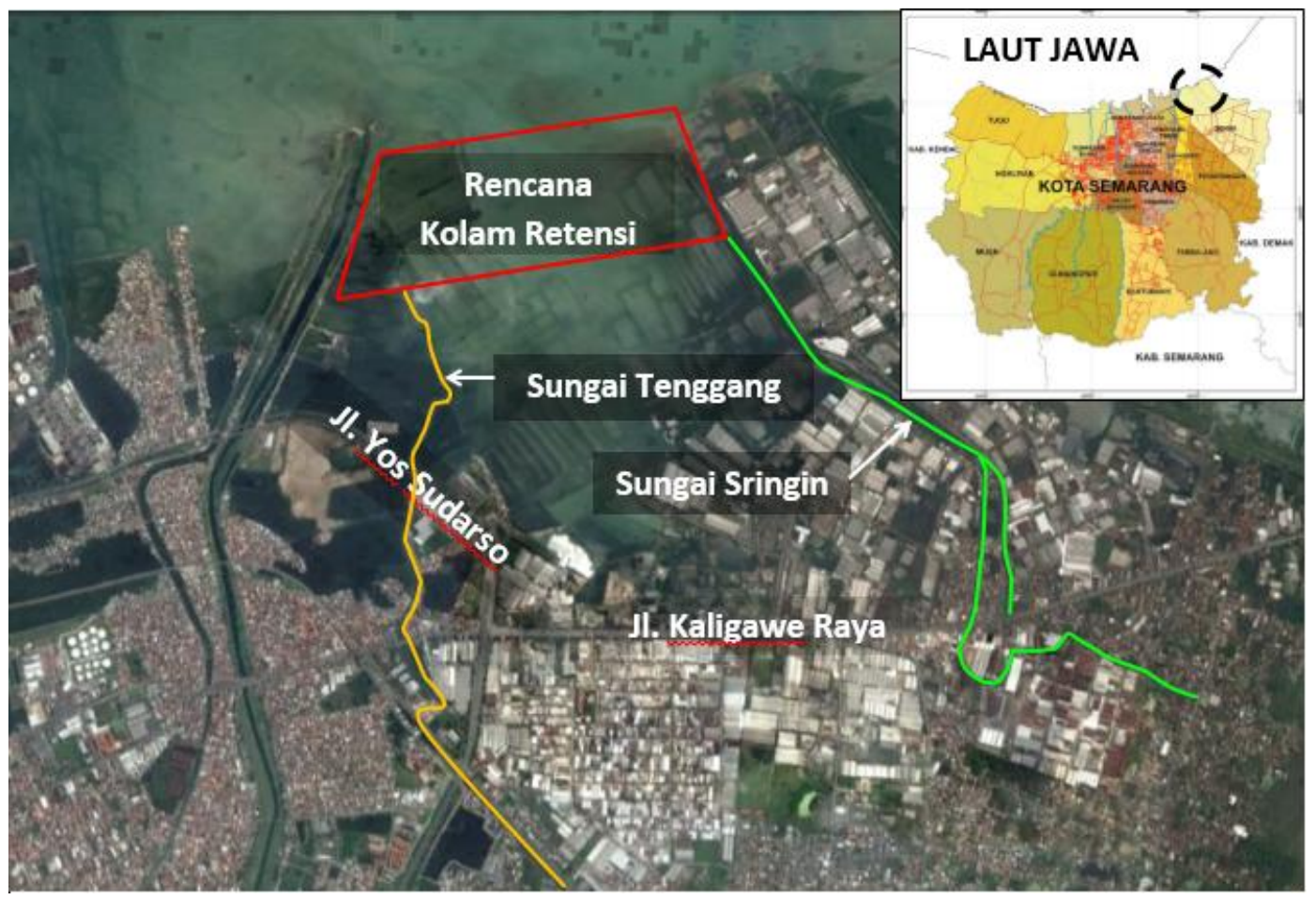

Gambar 2. Lokasi Studi di Wilayah Semarang Timur

a. Biaya Konstruksi

Pada luas kolam retensi 100 ha- 300 ha memiliki harga pekerjaan Geotube, Tanggul laut, rumah pompa, rumah operator pompa dan penanaman mangrove yang sama, namun harga pekerjaan kolam retensi tiap luasan berbeda.

b. Biaya Konsultan Teknik
Biaya teknik yang dibutuhkan dalam proyek pembangunan Sistem polder Semarang Timur diperkirakan sebesar $15 \%$ dari keseluruhan biaya konstruksi. Sehingga biaya teknik yang dibutuhkan sebesar:

Biaya Konsultan Teknik

$=15 \% \times$ Biaya Konstruksi

$=15 \% \times \operatorname{Rp} 574.168 .000 .000,00$

$=\operatorname{Rp} 86.125 .200 .000,00$ 
c. Biaya Pengadaan Pompa

Berdasarkan wawancara dengan salah satu pabrik pompa di indonesia, didapat estimasi biaya pompa jenis submersible dengan kapasitas $2,5 \mathrm{~m}^{3} / \mathrm{s}$ yaitu sebesar $\mathrm{Rp}$ 3.000.000.000,00 sedangkan untuk kapasitas $5 \mathrm{~m} 3 / \mathrm{s}$ sebesar $\mathrm{Rp}$ 6.000.000.000,00.

Tabel 1. Biaya Konstruksi

\begin{tabular}{|c|c|c|}
\hline No & JENIS PEKERJAAN & HARGA \\
\hline I & PEKERJAAN GEOTUBE & 2.851 .383 .000 \\
\hline II & $\begin{array}{l}\text { PEKERJAAN KOLAM } \\
\text { RETENSI }(210 \mathrm{ha})\end{array}$ & $395,461515.059$ \\
\hline III & $\begin{array}{l}\text { PEKERJAAN TANGGUL } \\
\text { LAUT }\end{array}$ & 31.901 .575 .257 \\
\hline IV & $\begin{array}{l}\text { PEKERJAAN RUMAH } \\
\text { POMPA }\end{array}$ & 35.145 .025 .325 \\
\hline $\mathrm{V}$ & $\begin{array}{l}\text { PEKERJAAN RUMAH } \\
\text { OPERATOR POMPA }\end{array}$ & 313.108 .206 \\
\hline VI & $\begin{array}{l}\text { PEKERJAAN PENANAMAN } \\
\text { MAGROVE }\end{array}$ & 12.800 .000 .000 \\
\hline & Jumlah & 478.472 .606 .849 \\
\hline & Pajak (PPN 10\%) & 47.847 .260 .684 \\
\hline & Overhead (10\%) & 47.847.260.684 \\
\hline & Jumlah Akhir & 574.167.128.219 \\
\hline & Pembulatan & 574.168 .000 .000 \\
\hline
\end{tabular}

Lima Ratus Tujuh Puluh Empat Milyar Seratus Enam Puluh Delapan Juta Rupiah

(Sumber : Royna dan Agung, 2017 dengan modifikasi)

\section{Analisis Biaya Manfaat}

Manfaat langsung dari

Pembangunan Sistem Polder Semarang Timur ini adalah untuk mengatasi banjir dan rob. Berdasarkan Penelitian yang dilakukan oleh Pusat Penelitian Oseanografi, Prediksi luas genangan rob yang terjadi di wilayah Semarang Timur pada tahun 2030 yaitu sebesar 615,94 hektar.
Biaya manfaat pengendalian banjir dapat diketahui dari biaya kerugian akibat terjadinya banjir dan rob. Kerugian ekonomi akibat banjir dan rob dapat di hitung berdasarkan nilai ekonomi setiap penggunaan lahan. Pada penelitian ini, nilai ekonomi setiap penggunaan lahan wilayah semarang didasarkan pada penelitian lahan yang telah dilakukan oleh Ifan R Suhelmi, dkk (2013). Penentuan nilai ekonomi masing-masing penggunaan lahan dapat dilihat pada Tabel 2.

Tabel 2. Potensi kerugian genangan

\begin{tabular}{lr}
\hline Penggunaan Lahan & $\begin{array}{c}\text { Nilai Penggunaan Lahan } \\
\text { (Rupiah/Hektar) }\end{array}$ \\
\hline Pemukiman & 7.080 .295 .000 \\
$\begin{array}{l}\text { Gedung/Kawasan } \\
\text { industri }\end{array}$ & 9.179 .524 .000 \\
Tambak & 811.971 .000 \\
Lahan terbuka & 12.263 .000 \\
Jalan & 10.875 .000 .000 \\
Tubuh air & 0 \\
\hline \multicolumn{2}{c}{ (Sumber : Ifan R Suhelmi, dkk.2013) }
\end{tabular}

Luas genangan tiap penggunaan lahan dihitung dengan bantuan aplikasi Google Earth, hasil dari penggambaran tiap penggunaan lahan dapat dilihat pada Gambar 3. Setelah didapat luas gengan tiap penggunaan lahan, langkah selanjutnya yaitu menghitung biaya kerugian akibat banjir dan rob di Wilayah Semarang Timur.

Berdasarkan perhitungan Biaya Kerugian akibat Banjir dan Rob di Wilayah Semarang Timur didapatkan jumlah perkiraan kerugian banjir dan rob di Wilayah Semarang Timur yaitu sebesar Rp 2.844.064.046.700, 00. 


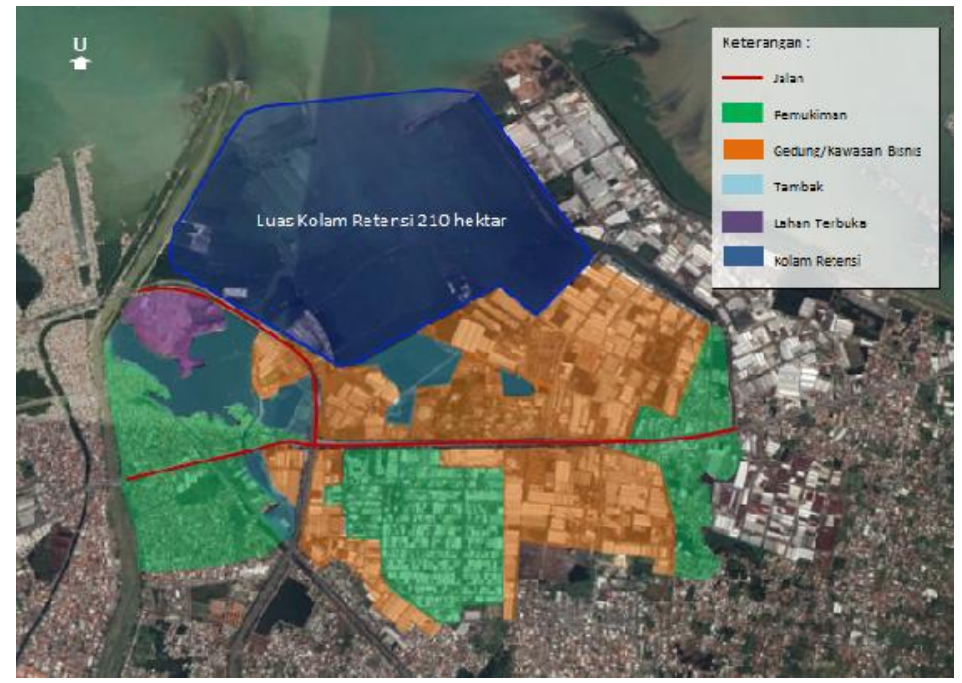

Gambar 3. Peta genangan banjir Wilayah Semarang Timur

Operasional pompa di dominasi menggunakan listrik dari PLN karena biayanya yang lebih murah dibandingkan menggunakan mesin diesel. Penggunaan pompa tergantung dari cuaca, ketika hujan maka dalam sehari pompa di nyalakan pagi dan sore selama kurang lebih 3 jam. Ketika musim kemarau maka dalam sehari pompa dinyalakan pagi dan sore selama kurang lebih 1,5 jam. Sedangkan untuk mesin Genset dinyalakan tiap hari selama 1-2 jam. Dari acuan tersebut, maka dapat di hitung estimasi biaya operasional pompa, yaitu sebagai berikut :

1. Rencana jenis Pompa Submersible yang digunakan :

- Pompa A, kapasitas (Q) $=2,50 \mathrm{~m}^{3} /$ detik, head $(\mathrm{H})=5 \mathrm{~m}$

- Pompa B, kapasitas (Q) $=5,00 \mathrm{~m}^{3} /$ detik, head $(\mathrm{H})=5 \mathrm{~m}$

2. Rencana Catu daya pengoperasian unit pompa, sebagai berikut :

- Genset 1.100 kVA untuk Pompa A - Genset 2.250 kVA untuk Pompa B

3. Konsumsi bahan bakar dan minyak pelumas mesin genset pada Tabel 3.

4. Harga bahan bakar solar dan pelumas

- Bahan bakar solar (per januari 2018industri) sebear Rp 9.550,00/liter

- Bahan pelumas mesin diesel (Mediterian SX) sebesar Rp 29.000,00/liter
Tabel 3. Konsumsi Bahan bakar dan Minyak Pelumas Genset

\begin{tabular}{cccc}
\hline $\begin{array}{c}\text { Type } \\
\text { Genset }\end{array}$ & $\begin{array}{c}\text { Konsumsi } \\
\text { Bahan Bakar } \\
\text { (liter/jam/unit) }\end{array}$ & $\begin{array}{c}\text { Kebutuhan } \\
\text { pelumas } \\
\text { mesin } \\
\text { (liter) }\end{array}$ & $\begin{array}{c}\text { Pengganti } \\
\text { pelumas } \\
\text { (jam) }\end{array}$ \\
\hline $\begin{array}{c}1.100 \\
\text { kVA }\end{array}$ & 226 & 166 & 200 \\
2.250 & 496 & 280 & 200 \\
kVA & Sumber : SOP Stasiun Rumah Pompa \\
\hline \multicolumn{4}{r}{ Kali Semarang, 2014 }
\end{tabular}

5. Estimasi konsumsi energi listrik dan biaya PLN/jam

Tarif daya listrik Mengacu pada kepres No. 28 tahun 2016, tarif daya listrik untuk pelayanan bisnis non subsidi sebagai berikut :

6. Tarif beban Rp. 29.500,- per KVA (Daya terpasang $2500 \mathrm{kVA}$ )

Tarif beban/bulan $=$ Rp 73.750.000,--

Tarif beban/jam = Rp 102.431,-

7. Tarif pemakaian Rp. 1467 ,- per KWH

Biaya keseluruhan operasional dan Pemeliharaan 1 buah pompa A dan pompa B dalam setahun pada Sistem polder Semarang Timur dapat dilihat pada Tabel 4 berikut.

Tabel 4. Biaya Operasional dan Pemeliharaan Pompa/tahun

\begin{tabular}{ccc}
\hline Pompa & $\begin{array}{c}\text { 1 buah } \\
\text { Pompa A }\end{array}$ & $\begin{array}{c}\text { 1 buah } \\
\text { Pompa B }\end{array}$ \\
\hline Genset & 428.031 .000 & 721.980 .000 \\
\hline
\end{tabular}




\begin{tabular}{cr|r|}
\hline PLN & 594.135 .000 & 917.344 .440 \\
\hline Pemeliharaan & 342.888 .000 & 342.888 .000 \\
\hline Kantor & 334.000 .000 & 334.000 .000 \\
\hline Total & 1.877 .179 .000 & 2.663 .574 .440 \\
\hline \multicolumn{3}{c}{ Sumber $:$ Hasil Analisis, 2017}
\end{tabular}

\section{Parameter Ekonomi}

Tabel 5. Biaya yang timbul pada Sistem Polder Semarang Timur

\begin{tabular}{|c|c|c|c|}
\hline No & Jenis Biaya & Kode & Nominal/tahun \\
\hline 1 & $\begin{array}{l}\text { Pembebasan } \\
\text { Lahan }\end{array}$ & $\mathrm{L}$ & Rp157.500.000.000,00 \\
\hline 2 & $\begin{array}{l}\text { Konstruksi } \\
\text { (5 tahun) }\end{array}$ & K & Rp114.833.600.000,00 \\
\hline 3 & Pompa & $\mathrm{P}$ & Rp 18.000.000.000,00 \\
\hline 4 & $\begin{array}{l}\text { Teknik } \\
\text { (7 tahun) }\end{array}$ & $\mathrm{T}$ & $\operatorname{Rp} 12.303 .600 .000,00$ \\
\hline 5 & $\begin{array}{l}\text { Biaya } \\
\text { Operasional } \\
\text { dan } \\
\text { Pemeliharaan }\end{array}$ & $\mathrm{OP}$ & $\mathrm{Rp} \quad 8.012 .756 .880,00$ \\
\hline 6 & $\begin{array}{l}\text { Biaya } \\
\text { Manfaat }\end{array}$ & B & Rp.284.406.404.670,00 \\
\hline
\end{tabular}

Sehingga, dapat digambarkan Cash Flow Proyek Pembangunan Sistem Polder Semarang Timur dalam Gambar 4. Dari cash flow pada Gambar 4 didapat nilai NPV sebesar Rp 327.660.000.000,00 $(\mathrm{NPV}>0)$, NBC sebesar 1,39 $(\mathrm{NBC}>1)$ dan IRR sebesar $24 \%$. Dari nilai tersebut dapat disimpulakn bahwa Pembangunan Sistem Polder Wilayah Semarang Timur layah secara ekonomi.

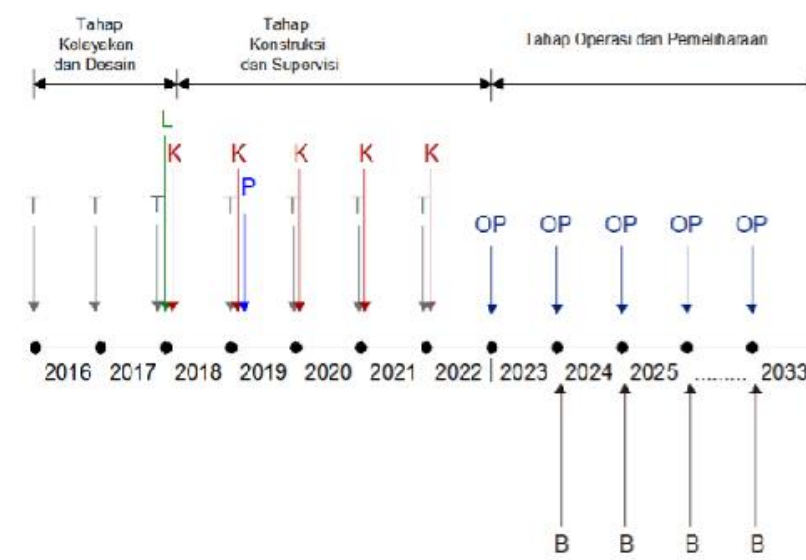

Gambar 4. Cash Flow

\section{KESIMPULAN}

Dilihat dari hasil analisis dan pembahasan tersebut diatas, maka dapat disimpulkan bahwa :
1. Didapatkan nilai Net Benefit Cost Ratio yaitu sebesar 1,39.

2. Didapatkan nilai Net Present Value yaitu sebesar Rp 327.660.000.000,00.

3. Didapatkan nilai Internal Rate of Return yaitu sebesar $24 \%$.

4. Hasil tinjauan kelayakan dari sisi ekonomi yang telah dibahas didapatkan beberapa parameter biaya yang di tinjau yaitu biaya pembebasan lahan, konstruksi, teknik, pengadaan pompa, operasional dan pemeliharaan serta biaya manfaat. Biaya tersebut kemudian di analisis berdasarkan parameter ekonominya. Dari hasil parameter ekonomi dapat di simpulkan Pembangunan Sistem Polder Wilayah Semarang Timur layah secara ekonomi.

\section{SARAN}

Berdasarkan hasil penelitian analisis dan pembahasan tersebut diatas, maka terdapat beberapa saran sebagai berikut:

1. Perlu adanya operasi yang terkoordinasi dengan baik dan pemeliharaan yang menerus dalam mengatasi banjir dan rob tersebut.

2. Partisipasi masyarakat dalam pembinaan, pengedalian dan penangulangan terhadap banji dan rob secara intensif dan terkoordinasi secara terpadu dengan meningkatkan kesadaran masyarakat misalnya dengan mengadakan peng-hijauan dan tata guna lahan yang ada sehingga dapat mengatasi permasalahan banjir dan rob di masa mendatang.

\section{DAFTAR PUSTAKA}

1. Darsono, Suseno, Susilowati dkk, Polder Semarang Timur, Pusat Studi Bencana LPPM Universitas Diponegoro, Semarang, 2016.

2. Giatman, M, Ekonomi Teknik, Jakarta, Raja Gravindo Persada, 2006.

3. maret 2011:53-60, 2011.

4. Kementerian Pekerjaan umum dan Perumahan Rakyar Dirjen Cipta 
Karya, Tata Cara Pembuatan Kolam Retensi (NSPM), Jakarta, KemenPUPR, 2011.

5. Kodoatie, RJ, Analisa Ekonomi Teknik, Andi Offset, Yogyakarta, 2011.

6. L, M Bakti, Kajian Sebaran Potensi Rob Kota Semarang Dan Usulan Penanganannya, Tesis pada Depatermen Teknik Sipil Fakultas Teknik Undip Semarang, 2011.

7. Permana, Adithya Bayu, Strategi Pengelolaan Sistem polder Kali Semarang yang Berkelanjutan, Tesis pada Depatermen Teknik Sipil Fakultas Teknik Undip, 2016.

8. Purnama, Setyawan dan Muh. Aris Marfai, Estimasi Risiko Kerugian Ekonomi Akibat Banjir dan Rob Menggunakan Sistem Informasi Geografis di Kecamatan Penjaringan, Jakarta Utara, SPATIAL Wahana Komunikasi dan Informasi Geografi Vol. 14 No.2 September, 2015.

9. S, A Pranoto, Ekonomi Rekayasa. Diktat Mata Kuliah Ekonomi Rekayasa, Universitas Diponegoro. 2008.

10. Sawarendro, Sistem Polder \& Tanggul Laut. Yogyakarta: ILWI (Indonesian Land Reclamation and Water Management Institute), 2010.

11. Suripin, Sistem Drainase Perkotaan yang Berkelanjutan, Andi Offset: Yogyakarta, 2004.

12. Yudi, Royna K dan Agung M N Perencanaan Sistem Polder Wilayah Semarang Timur. Jurnal Karya Teknik Sipil, Volume 6, Nomor 2, Tahun 2017, Halaman 265-275, 2017. 